Research Article

\title{
Improving students' motivation and collaborative skills through Remap Jigsaw learning combined with modelling activities
}

Sri Endah Indriwati a,1, ${ }^{*}$, Herawati Susilo a,2, I Made Surya Hermawan b,3

a Department of Biology, Faculty of Mathematics and Natural Sciences, Universitas Negeri Malang, Jl. Semarang No. 5 Malang, East Java 65145, Indonesia

${ }^{\mathrm{b}}$ Department of Biology Education, Graduate Program, Universitas Negeri Malang, Jl. Semarang No. 5 Malang, East Java 65145, Indonesia ${ }^{1}$ sri.endah.fmipa@um.ac.id*; 2 herawati.susilo.fmipa@um.ac.id; ${ }^{3}$ surya.hermawan17@gmail.com

${ }^{*}$ Corresponding author

ARTICLE INFO
Article history
Received March 15, 2019
Revised May 03, 2019
Accepted May 28, 2019
Published June 30, 2019
Keywords
Collaborative skills
Learning motivation
Remap Jigsaw
Modelling activities

\section{ABSTRACT}

Students' motivation and their collaborative skills play a crucial role in determining the learning quality. The lower the motivation and collaborative skills the lower the learning quality. This lesson study-based classroom action research aimed at improving the students' learning motivation and collaborative skills by implementing a Remap Jigsaw learning model. The subjects of this research were the fifth semester undergraduate students of Biology Education of Universitas Negeri Malang, who were taking the Basic Skills of Teaching course. The research was conducted in four cycles in which the each cycle consisted of two meetings. The instruments of data collection were the observation sheets and assessment sheets of students' self-report. The data was analyzed qualitatively and quantitatively. The results showed that students' learning motivation increased from $66.25 \%$ in the cycle I to $84.37 \%$ in the cycle IV; while the students' collaborative skills enhanced from $50 \%$ to $70.83 \%$ in the cycle IV. In the other words, the Remap Jigsaw combined with modelling activities can improve students' motivation and their collaborative skills.

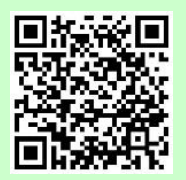

Copyright @ 2019 , Indriwati et al This is an open access article under the CC-BY-SA license

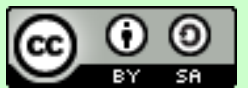

How to cite: Indriwati, S. E., Susilo, H. \& Hermawan, I. M. S. (2019). Improving students' motivation and collaborative skills through Remap Jigsaw learning combined with modelling activities. JPBI (Jurnal Pendidikan Biologi Indonesia), 5(2), 177-184. doi: https://doi.org/10.22219/jpbi.v5i2.7888

\section{INTRODUCTION}

Motivation is crucial factor in determining students' learning activity and achievement (Cahyono, Haryanto, \& Sudarsono, 2016). Learning motivation in the learning activity empowered through interactions and collaborations between students (Waite \& Davis, 2006) considering the student's motivation can appeal from themselves. Criollo-C and Luján-Mora (2019) argue students' motivation grows due to the interactions. In contrast, the collaborative skills not only empower the learning motivation but also improve the quality of lectures. According to Greenstein (2012), by the collaborative skill empowerment, the students can be trained to plan, conduct, and finish the task together. Students also can consider different points of view, participate via contribution, listen to, and support the other students' opinion (Greenstein, 2012; Perrault, McClelland, Austin, \& Sieppert, 2011). All 
those processes will build the interactions and social intelligence (Laske \& Visch, 2018), interpersonal skill, and make the learning more productive (Johnson \& Johnson, 2014).

The observation conducted during the Basic Skills of Teaching (BST) course in August 2017 described that the students' learning motivation was low shown by the students' activities during the lecture that less focused to the presentation and barely ask the question during the discussion step. The student felt sleepy, while some students did other subjects' homework when attending the BST course. The students remained lacking in collaborative skills. Even though the task given must be done in a group, however, the students prepared the presentation material individually. The lack of collaborative skills made students less understands the topic holistically so that it negatively impacted on the quality of the lecture.

The potential effort that can be done to overcome such a problem is by doing a learning model innovation. Learning model innovation includes innovations of the topic and detailed learning stages (Arends, 2012) so that the systematic and planned learning can be oriented to enhance the students' learning motivation and collaborative skills. Generally, the students' learning motivation and collaborative skills can be improved by many kinds of learning models involving the students actively (Corkin, Horn, \& Pattison, 2017) and centered to the students (Smit, de Brabander, \& Martens, 2014); one of them is cooperative learning.

The learning model that is potential to improve the students' learning motivation and collaborative skills simultaneously is a cooperative learning model. This case is because cooperative learning emphasizes the cooperative process to reach the goals together by accommodating the different views of students (Tombak \& Altun, 2016). One of the cooperative learning models that considered as the most effective model to improve learning motivation and collaborative skills is Jigsaw (Anggis, 2016; Tarhan, Ayyldız, Ogunc, \& Sesen, 2013; Ural, Ercan, \& Gençoğlan, 2017; Voyles, Bailey, \& Durik, 2015).

Various studies in several countries have reported the positive effects of applying jigsaw on students' motivation and collaborative skills (Tarhan et al., 2013; Tombak \& Altun, 2016; Ural et al., 2017). Jigsaw learning model which conducts outside the class considered can improve the cooperative skill between students in the United States (Halley, Heiserman, Felix, \& Eshleman, 2013). In Spain, cooperative learning including Jigsaw learning could increase students' learning motivation (Fernandez-Rio, Sanz, Fernandez-Cando, \& Santos, 2017). Meanwhile, similar research was also undertaken in Indonesia. The previous research results showed that Jigsaw enhanced students' learning motivation (Haryani, 2012; Lestari, Suniasih, \& Meter, 2014; Pertiwi, 2016; Ridlwan, 2016; Sulasmi, 2013; Trisianawati, Djudin, \& Setiawan, 2016), collaborative skills, and cognitive learning achievement (Anggis, 2016).

Jigsaw learning, on the other hand, has weakness in terms of different responses between students with high and low academic competence (Imam, Imam, \& Ikrar, 2018). Rather than low academic competence students, a student with high academic competence will be more responsive to handle the problem faced. Thus, combining Jigsaw with Remap is assumed to optimize learning. Remap is a new learning activity developed by Zubaidah (2014). In the Remap model, consists of reading, concept map making, and modelling activity (Zubaidah, 2014). Combining Jigsaw learning model Remap activity aims to prepare all students to have sufficient preconception of the discussion topic. This combining model can also reduce the variety of students' responses, which lead to an efficient learning process.

The previous studies reported that the combined Jigsaw and Remap has increased reading interest and critical thinking skills (Zubaidah, Duran Corebima, \& Mahanal, 2018). However, the study focused on the influence of the combination of learning motivation and collaborative skills was not conducted yet. Subsequently, the combination of Jigsaw and Remap of this research relied on the characteristic of the BST course. The BST course has the objective to enable the pre-service teachers to practice basic teaching skills such as explaining, asking, reinforcing, evaluating, etc. According to Salisu and Ransom (2014) these skills can be accommodated using modelling activities. Besides, modelling activities also supports the students' learning process and they can construct their knowledge independently (Salisu \& Ransom, 2014). Therefore, the combination of Remap-Jigsaw learning model and modelling activities assumed as a relevant alternative to help students achieve their learning objective, as well as improve their motivation and collaborative skills. This study aimed to improve students' learning motivation and collaborative skills through Remap-Jigsaw learning combined with modelling activities.

\section{METHOD}

This lesson study-based classroom action research consisted of three stages (plan, do, and see) per cycle. This study was conducted in four cycles. The "plan" stage was conducted by arranging the tools of research such as learning sources, learning media, and learning devices. The "do" stage was carried out by performing the learning process using Remap-Jigsaw learning model combined with modelling activities. The "see" stage was an evaluation of the learning process and focusing on evidence from the observation. This research was 
conducted in August - November 2017. The research subjects were 16 fifth semester-undergraduate students of Biology Education program from Universitas Negeri Malang taking the Basic Skill of Teaching course. The student's motivation was observed "Attention, Relevance, Confidence, and Satisfaction (ARCL)" learning motivation instrument adapted from Keller (2000). The collaborative skills instrument is adapted from Greenstein (2012). The scale of students' motivation was referred to Tembang, Sulton, and Suharjo (2017) and the collaborative skills were referred to Greenstein (2012) studies. The indicators involved are works productively, demonstrates respect, compromises, and shared responsibility (Greenstein, 2012). Students' learning motivation and collaborative skills were analysed qualitatively through data triangulation (Miles, Huberman, \& Saldaña, 2014) supported by descriptive data analysis.

\section{RESULTS AND DISCUSSION}

\section{Learning Motivation}

Students' learning motivation was measured using an observation sheet in each cycle of the meeting. Figure 1 presents the increase in the mean of learning motivation in cycle I, II, III, and IV. Based on Figure 1, the increment of students' learning motivation score (mean) from cycle I to cycle II was $2.5 \%$, from cycle II to cycle III was $5.743 \%$, and from cycle III to Cycle IV was $9.89 \%$.

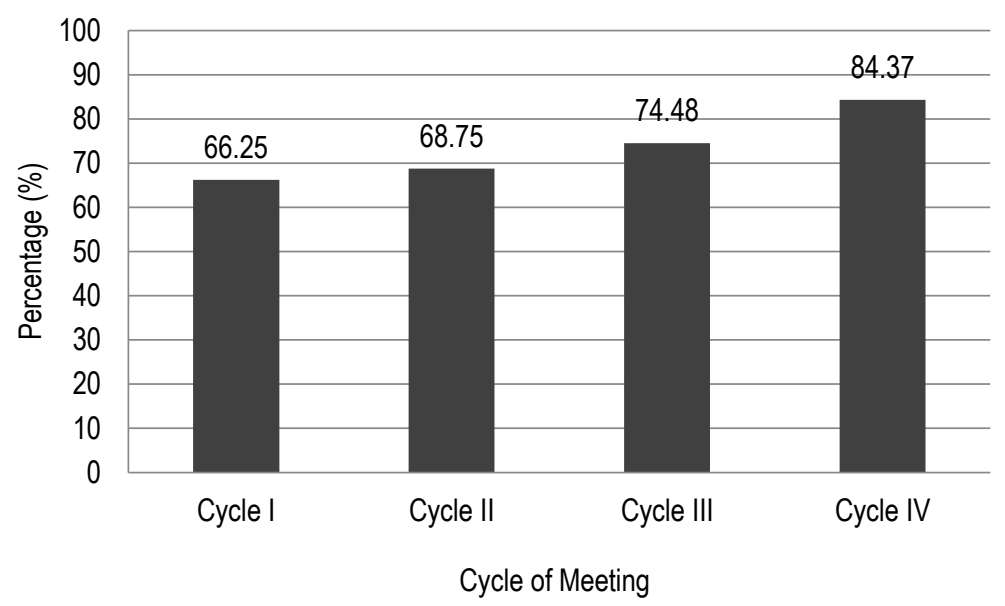

Figure 1. The diagram of the mean of classical learning motivation

The improvement of students' learning motivation was also supported by the qualitative data obtained from the students' self-expression written in their self-report. The following are the qualitative data of the students' statements related to the learning activity in enhancing the students' learning motivation.

".... This learning activity motivates me to have a deeper willingness in understanding the topic of the lesson since the method used was not boring as the previous learning methods where the learning in the class only focused on the presentation ...." $\left[\mathrm{H}^{*}\right]$

".... The lecture method by direct practice made me happy and helped me to understand the discussed topic ...." [YJ*]

"... I am very pleased and excited about following this lecture because I was not sleepy. The discussion was interesting. The modelling was also fun since it was conducted outside the room ...." [MR*]

*the student's initial name

Remap-Jigsaw learning model combined with modelling activities improved the students' learning motivation. The motivation enhancement occurred since this learning model grew up the individual responsibility of the student provided a meaningful and not boring learning experience. Şengül and Katranci (2014) stated that in Jigsaw learning model facilitate student to interact with each other during the learning. Furthermore, learning environment refers to social interactions during learning process positively contributes to the students' learning motivation (Arends, 2012; Pertiwi, 2016; Rachmah, 2017; Tarhan et al., 2013). Remap-Jigsaw model learning combined with modelling activities facilitates the student to interact more broadly and cooperatively. The 
interaction was also stimulated by the lecturer's role in the learning as the advisor as well as a learning friend supporting the achievement of the learning goals. Each student can actively contribute to the learning process and improve their motivation since there are some supported factors, i.e. social interactions between students and lecturer (Khamis, Dukmak, \& Elhoweris, 2008), lecturer's role in learning (Bolkan, 2015; Machingambi, 2013), cooperative (Ning \& Hornby, 2014), and collaborative learning method (Waite \& Davis, 2006). Uno and Koni (2013) also supported this statement by explaining the factors of external regulation also influenced the students' learning motivation.

The Remap-Jigsaw combined with modelling activities facilitated the students to be able to simulate the discussed topic. Besides, the discussion activity of Remap Jigsaw combined with modelling activity in the cycle III and IV was also conducted by Focus Group Discussion (FGD) method. This method caused the discussion in the learning more interactive between students and lecturers. Demonstration method, outdoor learning, and interactive discussion enhance the students' interest in joining the learning so that it positively impacts on the improvement of learning motivation (Bolkan, 2015). This argument is in line with the previous research reporting that learning using demonstration method (Basheer, Hugerat, Kortam, \& Hofstein, 2017) and outdoor learning (Cahyono et al., 2016) improved the learners' learning motivation. If it is viewed from self-determination theory, this case happens due to the factor of internal regulation in the form of students' interest and comfort during the lecture so that their learning motivation upgraded (Ryan \& Deci, 2000).

\section{Collaborative Skills}

The score results of the students' collaborative skills in learning using Remap-Jigsaw combined with modelling activity from cycle I, II, III, and IV can be seen in Figure 2. Figure 2 shows that the mean scores of students' collaborative skills in the cycle I and II did not show increment, while the mean scores from the cycle II to the cycle III increased $6.25 \%$, and from the cycle III to the cycle IV increased $14.58 \%$. The quantitative data were also supported by the qualitative data from the students' statements. The students' statements were written in their self-report.

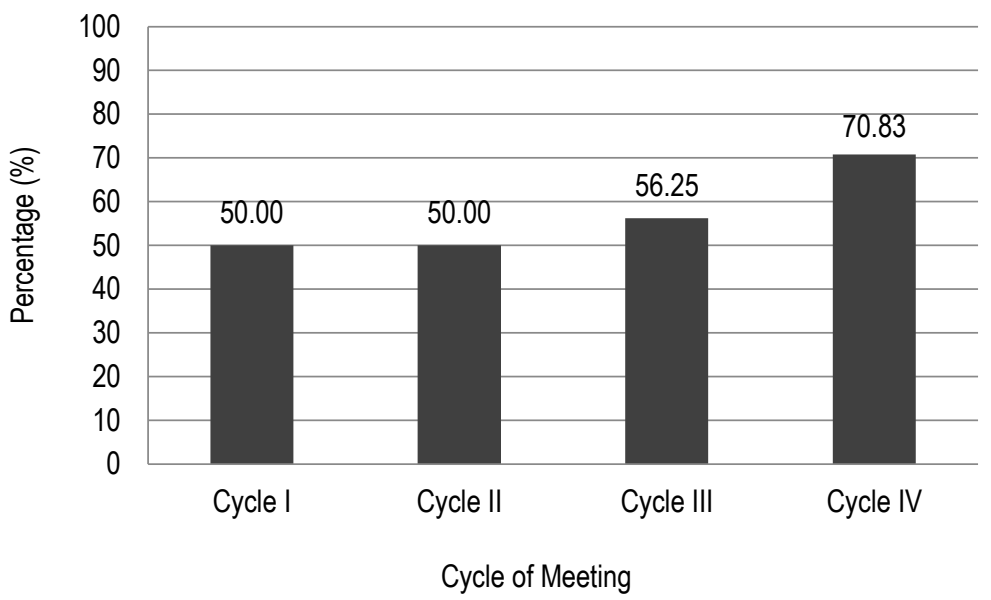

Figure 2. The diagram of the mean of student's classical collaborative skills

The mean scores of students' communication skill from cycle I to the cycle II did not increase since, in the group work, many students did not work collaboratively in the group because they were too passive and not too dominant. This case was also supported by the qualitative data in the form of students' responses to the learning activity as follow.

".... I see that one of the members of our group was less active but we often asked him to be courageous in expressing an opinion and helpful in the work ...." [UH*].

The students' collaborative skills increased from cycle II to the cycle III which was $6.25 \%$ and increased in the cycle IV which was $14.58 \%$. The increase in the mean scores of classical collaborative skills was also supported by the student' response as follow:

"... All group members took the role in modelling activity. We had tried to do our task optimally ..." $\left[A K N^{*}\right]$

*the student's initial name 
The respect between students also enhanced. The students felt that they had helped and cared each other. This case was modelled, although one student did not take the role as a model student; that student still assisted in the preparation of simulation. This case was stated by one student as follow:
".... As a student, I feel that my friends' assistance is very helpful, they solidly helped me to prepare the modelling activity ...." [UM"]
".... As a model-student, my friend still asked for my opinion; he did not selfishly prepare the modelling process ...." [CMD*]
".... Before modelling activity, we shared the task to each group member to make a lesson design, chapter design, and media. All group members accomplished the assigned task ...." [MR*]

The observed students' collaborative skills developed. When the students were given the chance to reflect the learning activity, they stated that in finishing the task, they shared the task so that they could accomplish the task well and on time. Two statements of the students are as follow:

1. ".... Our preparation for modelling could be said that it was immediate, but due to the participation of all group members and the responsibility of all tasks had been well accomplished and on time ...." [MR*]

2. ".... All group members did the task that had been shared previously; the job share was equal for all members ...." [UH*]

*the student's initial name

For collaborative skills, Remap-Jigsaw learning combined with modelling activities also gave positive effects. In the learning, the students were divided into the original group and expert group to solve a certain problem given by the lecturer. After that, the students were given the chance to design and practice the basic skill of teaching independently through modelling activity in the class. It means that Remap-Jigsaw learning combined with modelling activity provided a unity of the task of theory and practice that should be accomplished by the students together.

Remap-Jigsaw combined with modelling activity stimulated the individual responsibility through reading activity, discussion during the learning process, and modelling activity. Reading activity before learning requested the students to generate a topic resume that will be the material of a group discussion. In the discussion, each student group had the task to discuss a specific topic (expert group) that was then reported to all students including the expert group of the other topic. Subsequently, in modelling activity, every student group got a task to design a simulation of learning activity that would be modelled in front of the class. This argumentation is supported by Voyles et al. (2015) stating that Jigsaw learning model improved each student's responsibility.

During the discussion, the original group and expert group as the characteristic of Jigsaw, the students discussed the course topic in groups to generate a concept map as a product. In this activity, the students were actively involved to share the information each other so that they had a similar view of the focus of the topic that subsequently should be simulated in the modelling activity. The process of information sharing through multidirection communication and awareness in which they had the same goal is a significant aspect in empowering the collaborative skills. Such an argument is supported by some previous research stating that the important aspect to improve the students' collaborative skills are the goal formulation done together (Sturner, Bishop, \& Lenhart, 2017), comparing information each other (Schellens, Van Keer, \& Valcke, 2005), and respecting each other (Rotz \& Dueñas, 2016).

In the next stage, in the modelling activity, the students were given plenty of chances to design the simulation of learning activity independently (Salisu \& Ransom, 2014). In this process, the students were not limited to work in the class. They were free to design the simulation out of the learning time through face to face meeting or using the facility of information technology. Furthermore, during this activity, the students were asked to divide the individual task and responsibility as a model teacher, observer, and documenter to be succeeded in the modelling activity. The big chance of work and responsibility division to each group member positively contributed to the improvement of the students' collaborative skills. This case is in line with the statement of Rotz and Dueñas (2016) stating that the more freely use of the facility of technology and the great opportunity to work together enhanced the collaboration between students. Besides, the division of their task (Sturner et al., 2017) stimulating the trusting each other between students (Perrault et al., 2011) also positively influenced the enhancement of collaborative skill.

In another side, this research found some challenges which hinder the students' collaborative skills optimally. These challenges were shown by the stagnancy of the increase in the cycle I and II as well as the increase of $70.83 \%$ in the last cycle. The challenge was that not all students could understand the meaning of collaboration deeply. This case was shown by the fact that there were students that could elaborate the explanation in the 
discussion well, dominate in some aspects of the discussion, and tend to choose the friend that could be the workmates in one group. If the elaboration of explanation was weak, the student's domination was abundant, and there were tendency of the friendship. It was a challenge in developing the students' collaborative skills (Le, Janssen, \& Wubbels, 2018). This fact showed that the lecturer still faced some challenges to direct the students to be able to deliver the argument comprehensively, ensure the equal responsibility more effectively and remind that all students are the colleagues. This case aims to enhance the students' collaborative skills in the future.

\section{CONCLUSION}

Based on the research results and data analysis, it can be concluded that Remap-Jigsaw learning model combined with modelling activity improved the students' learning motivation and collaborative skills. The students' learning motivation increased from $66.25 \%$ in the cycle I, $68.75 \%$ in the cycle II, $74.48 \%$ in the cycle III, and $84.37 \%$ in the cycle IV while the students' collaborative skills enhanced from $50 \%$ in the cycle I and cycle II, $56.25 \%$ in the cycle III, and $70.83 \%$ in the cycle IV. Thereby, this study recommended the lecturers to apply Remap-Jigsaw learning model combined with modelling activity in the other courses to improve the students' learning motivation and collaborative skills including the pre-service student-teachers and general students that do not take the educational courses.

\section{REFERENCES}

Anggis, E. V. (2016). Penerapan model kooperatif Jigsaw berbasis lesson study untuk meningkatkan keterampilan kolaboratif dan hasil belajar kognitif. Proceeding Biology Education Conference, 13(1), 493497. Retrieved from https://jurnal.uns.ac.id/prosbi/article/view/5808/5194

Arends, R. I. (2012). Learning to teach (9th ed.). Retrieved from http://onlinelibrary.wiley.com/doi/10.1002/cbdv. 200490137/abstract

Basheer, A., Hugerat, M., Kortam, N., \& Hofstein, A. (2017). The effectiveness of teachers' use of demonstrations for enhancing students' understanding of and attitudes to learning the oxidation-reduction concept. EURASIA Journal of Mathematics, Science and Technology Education, 13(3), 555-570. doi: https://doi.org/10.12973/eurasia.2017.00632a

Bolkan, S. (2015). Intellectually stimulating students' intrinsic motivation: The mediating influence of affective learning and student engagement. Communication Reports, 28(2), 80-91. doi: https://doi.org/10.1080/ 08934215.2014 .962752

Cahyono, A., Haryanto, S., \& Sudarsono. (2016). Increasing motivation and science learning achievement through the implementation of outdoor cooperative learning model in Class VIII SMP 2 Banguntapan Academic Year 2015/2016. Journal of Education and Practice, 7(26), 21-26. Retrieved from https://files. eric.ed.gov/fulltext/EJ1115979.pdf

Corkin, D. M., Horn, C., \& Pattison, D. (2017). The effects of an active learning intervention in biology on college students' classroom motivational climate perceptions, motivation, and achievement. Educational Psychology, 37(9), 1106-1124. doi: https://doi.org/10.1080/01443410.2017.1324128

Criollo-C, S., \& Luján-Mora, S. (2019). Encouraging student motivation through gamification in engineering education. In M. E. Auer \& T. Tsiatsos (Eds.), Mobile Technologies and Applications for the Internet of Things (pp. 204-211). Springer International Publishing. Retrieved from https://link.springer.com/chapter/ 10.1007/978-3-030-11434-3_24

Fernandez-Rio, J., Sanz, N., Fernandez-Cando, J., \& Santos, L. (2017). Impact of a sustained cooperative learning intervention on student motivation. Physical Education and Sport Pedagogy, 22(1), 89-105. doi: https://doi.org/10.1080/17408989.2015.1123238

Greenstein, L. (2012). Assessing 21st century skills: A guide to evaluating mastery and authentic learning. California United State of America: Corwin Press. Retrieved from https://us.corwin.com/en-us/nam/asses sing-21st-century-skills/book237748

Halley, J., Heiserman, C., Felix, V., \& Eshleman, A. (2013). Students teaching students: A method for collaborative learning. Learning Communities Research and Practice, 1(3), 20. Retrieved from https://files .eric.ed.gov/fulltext/EJ1112670.pdf

Haryani, F. (2012). Meningkatkan motivasi dan pemahaman konsep perbandingan fungsi trigonometri melalui model pembelajaran jigsaw di SMA Negeri 8 Kota Jambi. Edu-Sains, 1(1), 33-37. Retrieved from https:// online-journal.unja.ac.id/index.php/edusains/article/view/792

Imam, P., Imam, S., \& Ikrar, P. (2018). Application of adobe flash media to optimize jigsaw learning model on 
geometry material. Journal of Physics: Conference Series, 1013, 012114. doi: https://doi.org/10.1088/ 1742-6596/1013/1/012114

Johnson, D. W., \& Johnson, R. T. (2014). Cooperative learning in 21st century. Anales De Psicología / Annals of Psychology, 30(3), 841-851. doi: https://doi.org/10.6018/analesps.30.3.201241

Keller, J. (2000). How to integrate learner motivation planning into lesson planning: The ARCS model approach. In VII Semanario. Santiago, Cuba. Retrieved from https://app.nova.edu/toolbox/instructionalproducts/ itde8005/weeklys/2000-keller-arcslessonplanning.pdf

Khamis, V., Dukmak, S., \& Elhoweris, H. (2008). Factors affecting the motivation to learn among United Arab Emirates middle and high school students. Educational Studies, 34(3), 191-200. doi: https://doi.org/10. 1080/03055690701811297

Laske, O., \& Visch, J. De. (2018). Dynamic collaboration: Strengthening self-organization and collaborative intelligence in teams. Retrieved from http://www.interdevelopmentals.org/wp-2016/wp-content/uploads/ 2018/04/ILR-Article-OL-3.pdf

Le, H., Janssen, J., \& Wubbels, T. (2018). Collaborative learning practices: Teacher and student perceived obstacles to effective student collaboration. Cambridge Journal of Education, 48(1), 103-122. doi: https:// doi.org/10.1080/0305764X.2016.1259389

Lestari, I. D. A. M., Suniasih, N. W., \& Meter, I. G. (2014). Pengaruh model pembelajaran kooperatif tipe TTW terhadap hasil belajar Bahasa Indonesia siswa kelas V SD Gugus IV Jimbaran Kecamatan Kuta Selatan. MIMBAR PGSD Undiksha, 2(1), 1-10. Retrieved from https://ejournal.undiksha.ac.id/index.php/JJPGSD/ article/view/1888/1640

Machingambi, S. (2013). Instructional strategies for motivating students: Reflections from 13 years of teaching in higher education. International Journal of Educational Sciences, 5(3), 227-235. doi: https://doi.org/10. 1080/09751122.2013.11890082

Miles, M. B., Huberman, A. M., \& Saldaña, J. (2014). Qualitative data analysis: A methods sourcebook (Third edit). Thousand Oaks, Califorinia: SAGE Publications, Inc. Retrieved from https://books.google.co.id/ books?id=3CNrUbTu6CsC

Ning, H., \& Hornby, G. (2014). The impact of cooperative learning on tertiary EFL learners' motivation. Educational Review, 66(1), 108-124. doi: https://doi.org/10.1080/00131911.2013.853169

Perrault, E., McClelland, R., Austin, C., \& Sieppert, J. (2011). Working together in collaborations: Successful process factors for community collaboration. Administration in Social Work, 35(3), 282-298. doi: https:// doi.org/10.1080/03643107.2011.575343

Pertiwi, K. (2016). Penerapan model pembelajaran kooperatif tipe jigsaw untuk meningkatkan motivasi dan hasil belajar pada mata pelajaran sosiologi siswa kelas XI IPS 1 SMA Negeri 5 Surakarta tahun pelajaran 2015/2016. SOSIALITAS; Jurnal IImiah Pend. Sos Ant, 7(2). Retrieved from https:/jurnal.fkip.uns.ac. id/index.php/sosant/article/view/8401

Rachmah, D. N. (2017). Effects of jigsaw learning method on students' self-efficacy and motivation to learn. Journal of Educational, Health and Community Psychology, 6(3), 1-9. Retrieved from https://pdfs. semanticscholar.org/e1ca/087e6e585218d54784f814684cd00e42b6fe.pdf

Ridlwan, N. H. (2016). Peningkatan motivasi dan hasil belajar siswa dengan model pembelajaran kooperatif tipe jigsaw plus. Bioedukasi, 14(1), 22-26. Retrieved from https://jurnal.unej.ac.id/index.php/BIOED/ article/view/4531/3354

Rotz, M. E., \& Dueñas, G. G. (2016). "Collaborative-ready" students: Exploring factors that influence collaboration during a longitudinal interprofessional education practice experience. Journal of Interprofessional Care, 30(2), 238-241. doi: https://doi.org/10.3109/13561820.2015.1086731

Ryan, R. M., \& Deci, E. L. (2000). Self-determination theory and the facilitation of intrinsic motivation, social development, and well-being. American Psychologist, 55(1), 68-78. doi: https://doi.org/10.1037/0003066X.55.1.68

Salisu, A., \& Ransom, E. N. (2014). The role of modeling towards impacting quality education. International Letters of Social and Humanistic Sciences, 32, 54-61. doi: https://doi.org/10.18052/www.scipress.com/ ILSHS.32.54

Schellens, T., Van Keer, H., \& Valcke, M. (2005). The impact of role assignment on knowledge construction in asynchronous discussion groups: A multilevel analysis. Small Group Research, 36(6), 704-745. doi: https://doi.org/10.1177/1046496405281771

Şengül, S., \& Katranci, Y. (2014). Effects of jigsaw technique on seventh grade primary school students' attitude towards mathematics. Procedia-Social and Behavioral Sciences, 116, 339-344. doi: https://doi.org/10. 
1016/j.sbspro.2014.01.218

Smit, K., de Brabander, C. J., \& Martens, R. L. (2014). Student-centred and teacher-centred learning environment in pre-vocational secondary education: Psychological needs, and motivation. Scandinavian Journal of Educational Research, 58(6), 695-712. doi: https://doi.org/10.1080/00313831.2013.821090

Sturner, K. K., Bishop, P., \& Lenhart, S. M. (2017). Developing collaboration skills in team undergraduate research experiences. PRIMUS (Problems, Resources, and Issues in Mathematics Undergraduate Studies ), 27(3), 370-388. doi: https://doi.org/10.1080/10511970.2016.1188432

Sulasmi, N. M. (2013). Penerapan model pembelajaran kooperatif tipe jigsaw untuk meningkatkan motivasi dan hasil belajar siswa pada mata pelajaran PKn di Kelas X 2 SMA Negeri 2 Banjar Tahun Ajaran 2012/2013. Jurnal Pendidikan Kewarganegaraan Undiksha, 1(4). Retrieved from https://ejournal.undiksha.ac.id/ index.php/JJPP/article/view/615/494

Tarhan, L., Ayyıldı, Y., Ogunc, A., \& Sesen, B. A. (2013). A jigsaw cooperative learning application in elementary science and technology lessons: physical and chemical changes. Research in Science \& Technological Education, 31(2), 184-203. doi: https://doi.org/10.1080/02635143.2013.811404

Tembang, Y., Sulton, S., \& Suharjo, S. (2017). Peningkatan motivasi dan hasil belajar melalui model pembelajaran think pair share berbantuan media gambar di sekolah dasar. Jurnal Pendidikan: Teori, Penelitian, dan Pengembangan, 2(6), 812-817. doi: https://doi.org/10.17977/jptpp.v2i6.9402

Tombak, B., \& Altun, S. (2016). The effect of cooperative learning: University example. Eurasian Journal of Educational Research, (64), 173-196. doi: https://doi.org/10.14689/ejer.2016.64.10

Trisianawati, E., Djudin, T., \& Setiawan, R. (2016). Pengaruh model pembelajaran kooperatif tipe jigsaw terhadap hasil belajar siswa pada materi vektor di kelas X SMA Negeri 1 Sanggau Ledo. Jurnal Penelitian Fisika dan Aplikasinya (JPFA), 6(2), 51. doi: https://doi.org/10.26740/jpfa.v6n2.p51-60

Uno, H. B., \& Koni, S. (2013). Assessmen pembelajaran. Jakarta: PT Bumi Aksara. Retrieved from https:// www.belbuk.com/assessment-pembelajaran-p-24475.html

Ural, E., Ercan, O., \& Gençoğlan, D. M. (2017). The effect of jigsaw technique on 6th graders' learning of force and motion unit and their science attitudes and motivation. Asia-Pacific Forum on Science Learning and Teaching, 18(1), 1-21. Retrieved from https://www.eduhk.hk/apfslt/download/v18_issue1_files/ural.pdf

Voyles, E. C., Bailey, S. F., \& Durik, A. M. (2015). New pieces of the Jigsaw classroom: Increasing accountability to reduce social loafing in student group projects. The New School Psychology Bulletin, 13(1), 11-20. Retrieved from https://pdfs.semanticscholar.org/b787/0f425f42d930a839e82c547b6f987e050b0c.pdf?_g $a=2.255901131 .1595346676 .1564374974-863561491.1563867587$

Waite, S., \& Davis, B. (2006). Developing undergraduate research skills in a faculty of education: motivation through collaboration. Higher Education Research \& Development, 25(4), 403-419. doi: https://doi.org/ 10.1080/07294360600947426

Zubaidah, S. (2014). The empowerment of discovery skills in scientific approach through Remap Coople based learning. In Seminar Nasional XI "Biologi, Sains, Lingkungan dan Pembelajarannya" (pp. 1-12). Universitas Sebelas Maret. Retrieved from https://www.researchgate.net/publication/322314942 PEMBERDAYAAN_KETERAMPILAN_PENEMUAN_DALAM_SCIENTIFIC_APPROACH_MELALUI_PE MBELAJARAN_BERBASIS_REMAP_COOPLE

Zubaidah, S., Duran Corebima, A., \& Mahanal, S. (2018). Revealing the relationship between reading interest and critical thinking skills through Remap GI and Remap Jigsaw. International Journal of Instruction, 11(2), 41-56. doi: https://doi.org/10.12973/iji.2018.1124a 